\title{
Rapid alteration of fractured volcanic conduits beneath Mt Unzen
}

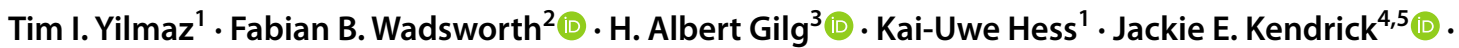 \\ Paul A. Wallace ${ }^{5,6}$ - Yan Lavallée ${ }^{5}$. James Utley ${ }^{5} \cdot$ Jérémie Vasseur $^{1} \cdot$ Setsuya Nakada ${ }^{7}$. Donald B. Dingwell ${ }^{1}$
}

Received: 1 November 2020 / Accepted: 8 March 2021 / Published online: 16 April 2021

(c) The Author(s) 2021

\begin{abstract}
The nature of sub-volcanic alteration is usually only observable after erosion and exhumation at old inactive volcanoes, via geochemical changes in hydrothermal fluids sampled at the surface, via relatively low-resolution geophysical methods or can be inferred from erupted products. These methods are spatially or temporally removed from the real subsurface and thus provide only indirect information. In contrast, the ICDP deep drilling of the Mt Unzen volcano subsurface affords a snapshot into the in situ interaction between the dacitic dykes that fed dome-forming eruptions and the sub-volcanic hydrothermal system, where the most recent lava dome eruption occurred between 1990 and 1995. Here, we analyse drill core samples from hole USDP-4, constraining their degree and type of alteration. We identify and characterize two clay alteration stages: (1) an unusual argillic alteration infill of fractured or partially dissolved plagioclase and hornblende phenocryst domains with kaolinite and Reichweite 1 illite (70)-smectite and (2) propylitic alteration of amphibole and biotite phenocrysts with the fracture-hosted precipitation of chlorite, sulfide and carbonate minerals. These observations imply that the early clayforming fluid was acidic and probably had a magmatic component, which is indicated for the fluids related to the second chlorite-carbonate stage by our stable carbon and oxygen isotope data. The porosity in the dyke samples is dominantly fracture-hosted, and fracture-filling mineralization is common, suggesting that the dykes were fractured during magma transport, emplacement and cooling, and that subsequent permeable circulation of hydrothermal fluids led to pore clogging and potential partial sealing of the pore network on a timescale of $\sim 9$ years from cessation of the last eruption. These observations, in concert with evidence that intermediate, crystal-bearing magmas are susceptible to fracturing during ascent and emplacement, lead us to suggest that arc volcanoes enclosed in highly fractured country rock are susceptible to rapid hydrothermal circulation and alteration, with implications for the development of fluid flow, mineralization, stress regime and volcanic edifice structural stability. We explore these possibilities in the context of alteration at other similar volcanoes.
\end{abstract}

Keywords Permeability $\cdot$ Arc volcano $\cdot$ Edifice stability $\cdot$ Clay minerals $\cdot$ Hydrothermal

Editorial responsibility: R. Cioni

Fabian B. Wadsworth

fabian.b.wadsworth@durham.ac.uk

1 Department of Earth and Environmental Sciences, LudwigMaximilians-Universität München (LMU), Theresienstrasse 41/III, 80333 Munich, Germany

2 Department of Earth Sciences, Durham University, Durham DH1 3LE, UK

3 Division: Engineering Geology, Technical University of Munich (TUM), Arcisstr. 21, 80333 Munich, Germany

4 Grant Institute, University of Edinburgh, King's Buildings, West Mains Road, Edinburgh EH9 3JW, UK
5 Department of Earth, Ocean and Ecological Sciences, University of Liverpool, 4 Brownlow Street, Liverpool L69 3GP, UK

6 Department of Geosciences, Environment and Society, Université Libre de Bruxelles, Avenue Franklin Roosevelt 50, 1050 Brussels, Belgium

7 National Research Institute for Earth Science and Disaster Resilience, Tennodai, Tsukuba 305-0006, Japan 


\section{Introduction}

The evolving geometry, temperature distribution, fluid circulation rates, hydraulic properties and composition of the shallow subsurface below active volcanoes are both transient and obscured by the volcanic edifice. As such, they can be difficult to resolve. Yet these features of the region beneath an active volcanic vent are key to understanding how the system will evolve, and involve strong feedbacks between chemical and physical processes over a large range of scales (Delmelle et al. 2000; Kumagai et al. 2002; Ikeda et al. 2008; Heap et al. 2017, 2019; Cashman et al. 2017; Sparks et al. 2019). While there is some evidence that shifts in hydrothermal circulation, temperature and alteration during repose periods of active volcanoes may be important for subsequent eruptive activity (Mordensky et al. 2019a; Heap et al. 2019), the extent to which there is a causal link between alteration and eruptive behaviour remains unclear. This uncertainty arises, in part, from the paucity of in situ data that shed light on the time evolution of volcanic alteration in the subsurface.

Persistent or slow-growing volcanic domes commonly host hydrothermal alteration minerals in their structure and conduit feeding system (Ball et al. 2013, 2015; RosasCarbajal et al. 2016; Byrdina et al. 2017; Wallace et al. 2019). Hydrothermal mineral alteration can reduce the permeability of the rock (Horwell et al. 2013; Ball et al. 2015; Heap et al. 2019), which has been inferred to be a mechanism by which pore pressure can build, potentially causing rupture via pore pressure embrittlement (Shiina et al. 2013; Farquharson et al. 2016) which in turn may lead to an explosive eruption episode (e.g. Heap et al. 2019). Evidence exists to suggest that whereas fracture porosity is increased during dome emplacement and cooling (Cordonnier et al. 2009; Wadsworth et al. 2018), the pore network can be sealed during hydrothermal circulation and mineral precipitation (Ball et al. 2015). Additionally, hydrothermal alteration and mineralization may weaken edifice rocks and increase the likelihood of edifice collapse (López and Williams 1993; Rosas-Carbajal et al. 2016). Despite their proposed importance for volcanic behaviour, opportunities to study the in situ evolution of alteration, permeability or ore-forming processes below active volcanoes are generally lacking, with the result that dynamic processes must be reconstructed from eroded, fossil examples or erupted products, from fluid chemistry data, from laboratory experiments or from geophysical surveys. In general, electrical resistivity can be effective for building a picture of the hydrothermal system beneath a volcanic edifice (Byrdina et al. 2017), but has the drawback of being indirect and low-resolution compared with direct sampling. The Unzen Scientific Drilling Project (USDP-4) provides a dramatic exception to this state of affairs. Core drilled between 2003 and 2004 provides a direct opportunity to examine in situ alteration on a decadal timescale.

Intermediate-to-silicic magmas moving from volatilerich storage conditions toward the Earth's surface are thought to encounter the circumstances required for pervasive, in-conduit magma fracturing, opening pore space (Gonnermann and Manga 2003; Lavallée et al. 2007; Cordonnier et al. 2009, 2012; Coats et al. 2018; Wadsworth et al. 2018; Hornby et al. 2019). The formation of fractures in magma increases their permeability to fluids (Lavallée et al. 2013; Heap and Kennedy 2016; Colombier et al. 2017; Lamur et al. 2017; Vasseur and Wadsworth 2019) and may therefore promote intra-conduit circulation of magmatic or external hydrothermal fluids (Wallace et al. 2019). In turn, this circulation is likely to change the regime in which the entire edifice exchanges heat and mass (via precipitation or dissolution) with the rising or stagnant magma (Ghassemi and Suresh Kumar 2007; Rowland and Simmons 2012).

Volcano-hosted hydrothermal systems are highly dynamic and involve magmatic, meteoric and, occasionally, basin fluids. Various alteration types are frequently superimposed and may comprise both hypogene and supergene hydrothermal minerals complicating the interpretation of the observed mineral assemblage, especially when clay minerals are investigated (Sheppard et al. 1969; Kyne et al. 2013). The temperatures of specific clay mineral formation stages are as yet poorly constrained (Seedorff et al. 2005; Wilson 2013). This is especially so in the complex and open-system environments typical of natural systems. Here, we document the preservation of a high-temperature clay alteration assemblage encountered by deep drilling of a volcanic conduit system at Mt Unzen, Japan. We use a suite of analytical tools to decipher the distribution and paragenetic sequence of alteration minerals in drill core samples including optical, cathodoluminescence, and automated scanning electron microscopy (QEMSCAN). Mineral identification was based on X-ray diffraction (XRD) analysis of bulk samples and of oriented mounts of clay-sized separates with additional information from electron microprobe analysis (EPMA), infrared and Raman spectroscopy. Our investigation sheds light on the paragenetic evolution and temperatures of nascent clay alteration in a volcanic system. In concert, these techniques permit us to build a coherent snapshot of the alteration as it was at the time and depth of drilling, which we can compare to the relatively pristine dome material at the surface (we note that the dome is not without alteration, but is relatively pristine compared with the subsurface examined herein). 


\section{Background: Mt Unzen}

Mt Unzen volcano is located on the Shimabara peninsula, within the back arc of the Ryukyu arc in the Beppu-Shimabara Graben, SW Japan. The volcano last erupted a lava dome comprising a series of 13 lobes between 1991 and 1995. The USDP-4 drilling (February 2003 to July 2004) penetrated Mt Unzen volcano from north to south with a total length of $1995.75 \mathrm{~m}$, in order to sample the eruptive feeder dyke(s). During drilling, an 400-m-wide conduit zone was identified and samples were recovered (Fig. 1). The conduit zone is made up of multiple, parallel, coherent dacite dykes, breccias, and tuffisite (volcaniclastic) veins, each up to $40 \mathrm{~m}$ wide, which intruded into a polymict vent breccia (Nakada et al. 2005). Samples C8 and C13-C16 are coherent dyke material. Within the C13-C16 dyke swarm, four parallel, but individual dykes were identified petrologically (Goto et al. 2008). Chemical and textural comparison of the subsurface dykes to the 1991-1995 eruptive materials has resulted in equivocal matches, with some studies associating some or all of the subsurface dyke swarm as the feeder system for the surface domes and lavas (Almberg et al. 2008; Noguchi et al. 2008; Goto et al. 2008). This is discussed later in the context of our results.
The down-hole temperature measured during the drilling of the dykes was $160-180{ }^{\circ} \mathrm{C}$ (Ikeda et al. 2008). The flanks of Unzen volcano and the surrounding Shimabara Peninsula exhibit numerous hot springs: evidence of an active hydrothermal system (Saibi and Ehara 2010) and Srigutomo et al. (2008) revealed a large-scale low-resistivity structure suggesting a water-saturated and altered layer in the Unzen area at $100 \mathrm{~m}$ to $2.5 \mathrm{~km}$ b.s.1., and mud logs revealed high gas concentrations around the areas of the drilled dykes (Kagiyama et al. 1999). Taken in concert the active hot springs and the geophysical evidence for a water-saturated edifice, suggest high permeability within the generally low-porosity dykes $(\sim 0.01-0.3$ volume fraction; Almberg et al. 2008), consistent with their fractured state (Goto et al. 2008), which favoured outgassing (Nakada et al. 2005) and fluid flux.

\section{Materials and methods}

USDP-4 drill core samples were analysed using a combined mineralogical, optical and geochemical approach. The cores were sub-sampled according to the description given by Goto et al. (2008). Each sub-sample was prepared for subsequent analysis by the methods described here.

Optical hot cathodoluminescence (CL) microscopy was conducted using a HC3-LM Simon-Neuser CL microscope
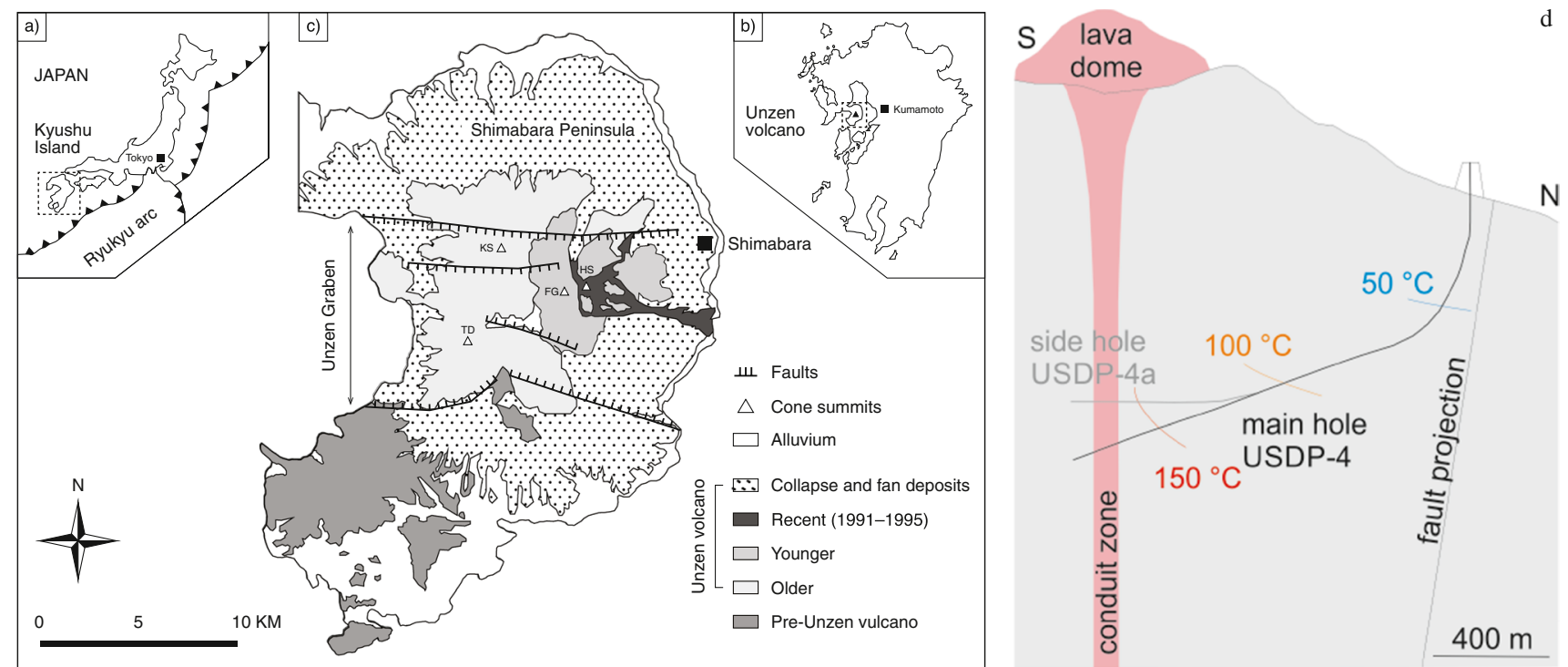

Fig. 1 (a-c) The location of Mt Unzen and the site of the USDP-4 drilling. (a) Map of Japan with the location of the southern detail map of Kyushu Island shown in (b) given in a dashed box. (b) The location of the Shimabara peninsular region in the dashed box and Mt Unzen volcano marked. (c) A simplified geological map of the Shimabara peninsula with the location of the Unzen Graben, where TD is Takadake, KS is Kusenbudake, FG is Fugendake and HS is
Heiseishinzan (Sugimoto et al. 2005). (d) A schematic trajectory of USDP-4 drill hole through the Mt Unzen volcano subsurface, showing the temperature isotherms intersected by the USDP-4 drill hole, terminating just beyond the conduit zone beneath the 1991-1995 lava dome at the surface (redrawn after Sakuma et al., 2008). In 3 dimensions, there is evidence that the conduit is inclined (Umakoshi et al. 2001; Lamb et al. 2015), which is not depicted here 
(Neuser et al. 1995) coupled with a Kappa PS 40C-285 (DX) camera system with a resolution of $1.5 \mathrm{mpx}$ attached to an Olympus BH-2 microscope. An electron gun operated at $14 \mathrm{keV}$ under a high vacuum of $10^{-4}$ bar with a filament current running at $0.18 \mathrm{~mA}$ was used in which the electron beam diameter was $\sim 0.4 \mathrm{~cm}$. The uncovered and polished thin sections of representative samples were coated with a carbon layer for $\mathrm{CL}$ imaging. The exposure times were 0.277 to $1.25 \mathrm{~s}$ for the $5 \times$ objective and 12.6 to $22.2 \mathrm{~s}$ for the $10 \times$ objective.

For bulk rock XRD analysis, the samples were disaggregated and ground for $8 \mathrm{~min}$ with $10 \mathrm{ml}$ of isopropyl alcohol. The powder mounts of the samples were analysed with a Philips PW 1800 X-ray diffractometer (CuKo, graphite monochromator, $10 \mathrm{~mm}$ automatic divergence slit, stepscan $0.02^{\circ} 2 \theta$ increments per second, counting time $1 \mathrm{~s}$ per increment, $40 \mathrm{~mA}, 30 \mathrm{kV}$ ). Quantification of the crystalline phases in the whole rock powders was performed using the Rietveld program BGMN (Bergmann et al. 1998). Additional XRD analysis of the $<2 \mu \mathrm{m}$ fractions, which were separated from the bulk material by gravitational settling in Atterberg cylinders, allowed us to identify the clay minerals. The composition of interstratified clay minerals was determined using tables in Moore and Reynolds (1989) and the BGMN structure model of Ufer et al. (2012a, b).

Chemical compositions of minerals were obtained using a Cameca SX100 electron microprobe. The accelerating voltage was $15 \mathrm{kV}$ with an electron beam current of $5 \mathrm{nA}$, and a defocused spot diameter of $5 \mu \mathrm{m}$ was used. The counting time was $10 \mathrm{~s}$ for $\mathrm{Si}, \mathrm{Al}, \mathrm{K}$ and $\mathrm{Na}$, and $30 \mathrm{~s}$ for $\mathrm{Ca}, \mathrm{Fe}, \mathrm{Mg}$, $\mathrm{Mn}, \mathrm{Ti}$ and $\mathrm{Cr}$ and half this time for the background. The standards used were wollastonite for $\mathrm{Si}$ and $\mathrm{Ca}$, albite for $\mathrm{Al}$, ilmenite for $\mathrm{Ti}$, hematite for $\mathrm{Fe}$, periclase for $\mathrm{Mg}$, ilmenite for $\mathrm{Mn}$, albite for $\mathrm{Na}$, orthoclase for $\mathrm{K}$ and chromite for $\mathrm{Cr}$. The data were corrected according to the PAP procedure (Pouchou and Pichoir 1985).

Scanning electron microscopy imaging was conducted using a Hitachi SU 5000 field emission scanning electron microscope equipped with an AZtecEnergy Advanced EDX system with an SDD detector operating at $20 \mathrm{keV}$.

QEMSCAN® (Quantitative Evaluation of Minerals by Scanning Electron Microscopy) analysis was performed using a QEMSCAN WellSite equipped with two Bruker energy dispersive X-ray (EDS) detectors attached to a Hitachi SU5000 FE-SEM. Uncovered, polished thin sections were carbon coated and scanned in an automated raster pattern collecting X-ray spectra along a grid (after Gottlieb et al. 2000). Whole thin sections were scanned using a $25-\mu \mathrm{m}$ step size to assess bulk mineralogy, while a higher resolution 2- $\mu \mathrm{m}$ step size was used to visualize local mineral alteration. Measurements were collected in field scan mode using a $15-\mathrm{kV}$ accelerating voltage, approximately $5 \mathrm{nA}$ beam current and acquiring 1000
X-ray counts per spectrum. Through collecting EDS data from each point, individual minerals were differentiated using chemical composition from secondary X-ray information. The resulting data is compared and matched to an extensive mineral database and augmented with petrographic observations using optical microscopy and Raman spectroscopy. Mineral statistics were performed using iDiscover software providing quantitative modal mineralogy and phase distribution maps.

Alteration phases were identified by micro-Raman spectroscopy using a Horiba Jobin Yvon XploRA PLUS confocal Raman microscope. The spectrometer is equipped with a frequency-doubled Nd:YAG laser $(532 \mathrm{~nm}$, with a maximum power of $22.5 \mathrm{~mW}$ ) and an Olympus $100 \times$ long working distance objective with a numerical aperture of 0.9. Measurements were performed using a $1200-\mathrm{mm}^{-1}$ grating with a 300- $\mu \mathrm{m}$ pinhole and a 100- $\mu \mathrm{m}$ slit and 2 accumulations of $10 \mathrm{~s}$ each.

Carbonate samples were extracted using a mounted diamond point (diameter of $1 \mathrm{~mm}$ ) under a ZEISS SteREO Discovery V8 binocular microscope. The carbonate powders were reacted with $100 \%$ phosphoric acid at $70{ }^{\circ} \mathrm{C}$ using a GasBench II connected to a Thermo Fisher Delta V Plus mass spectrometer. All values are reported in permil (\%o) relative to V-PDB for carbon and V-SMOW for oxygen using international standards for calibration, NBS-19 and LSVEC for carbon and NBS-19 and NBS18 for oxygen, respectively. The reproducibility and precision was monitored by replicate analysis of an internal laboratory standard (Solnhofen Limestone Sol-2) during the course of the study and found to be better than $0.15 \%$ o $(n=10,3 \sigma)$. Oxygen isotope values of Fe-rich dolomite were corrected using the phosphoric acid fractionation factors of Rosenbaum and Sheppard (1986).

\section{Results and analysis}

We focus our analysis on the conduit dyke samples (C8 and $\mathrm{C} 13-\mathrm{C} 16)$. Point counting analysis indicates a primary mineralogy in the green to pale grey porphyritic (20-40 vol.\% phenocrysts) dacite dyke samples that include abundant plagioclase (14-28 vol. \%; $\leq 5 \mathrm{~mm}$ ), heavily altered or completely pseudomorphed amphibole (primarily hornblende; 7-13 vol.\%; $\leq 3 \mathrm{~mm}$ ), partly altered biotite (2-3 vol.\%; $\leq 1 \mathrm{~mm})$ and minor quartz phenocrysts $(1-2$ vol. $\% ;<1 \mathrm{~mm}$ ) within a fine-grained groundmass (Figs. 2 and 3). Minor accessory phases such as apatite and zircon occur locally. The microcrystalline groundmass of C13-C16 consists of anhedral quartz, partly euhedral plagioclase and alkali feldspar $(<30 \mu \mathrm{m})$. Sample C8, however, is characterized by coarser grained euhedral plagioclase microlites $(<120 \mu \mathrm{m})$. The dykes are selectively altered and show a 


\section{a}
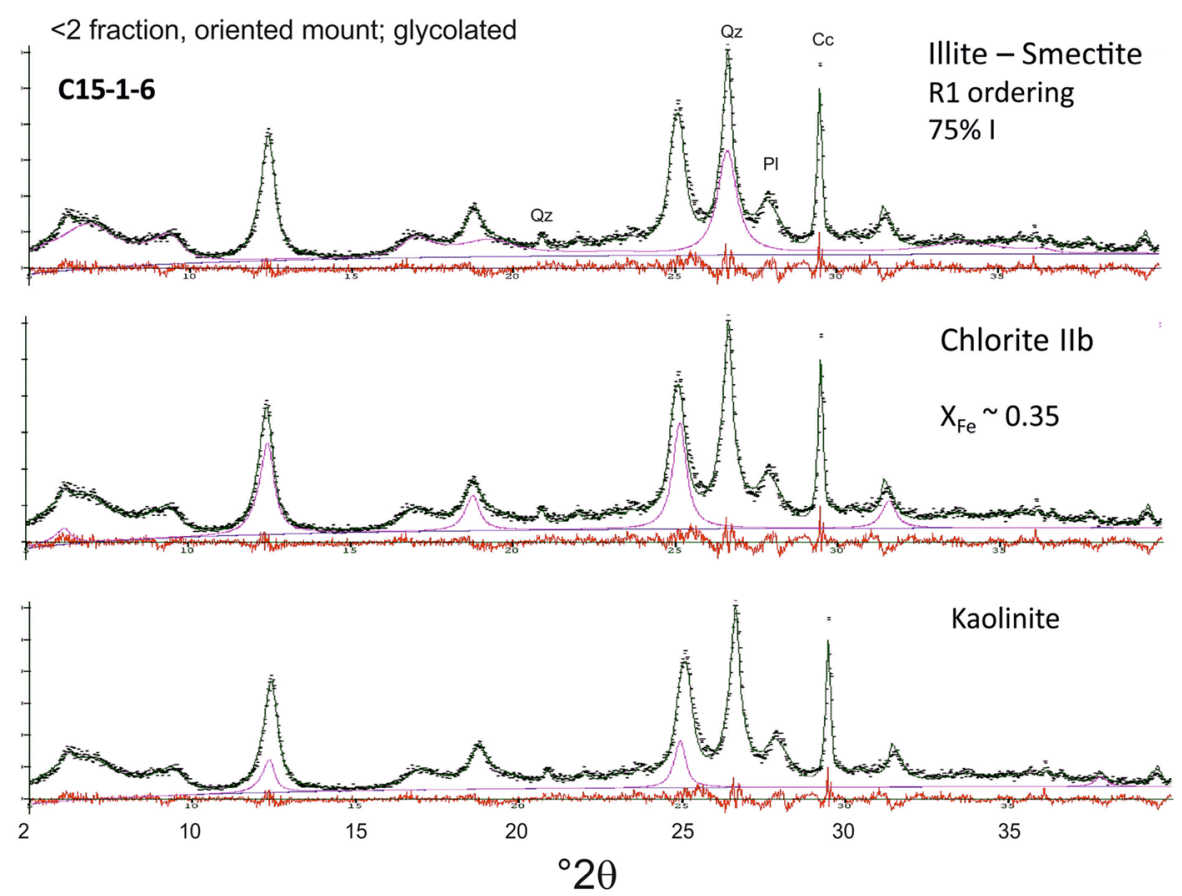

b

Kaolinite C16-2-6
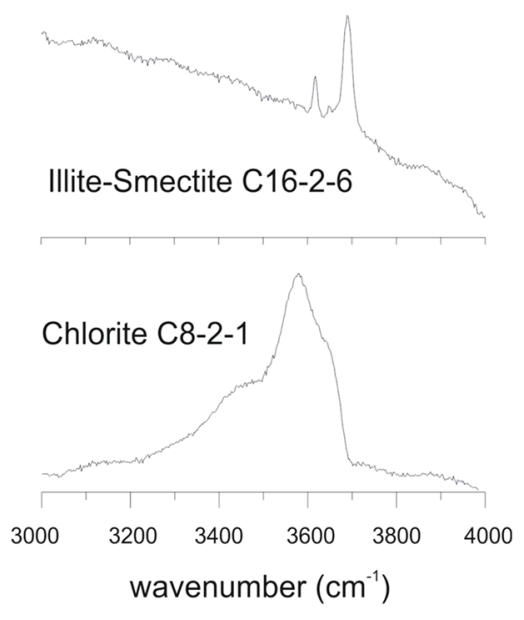

Fig. 2 Identification of clay minerals using XRD and Raman spectroscopy highlighting the mineralogy of the clay alteration stages documented here in the Unzen subsurface. (a) Rietveld refinement graph of an XRD pattern of an oriented, glycolated mount of the $<2-\mu \mathrm{m}$ fraction of sample C15-1-6. It shows the presence of the three clay minerals in magenta in addition to traces of quartz $(\mathrm{Qz})$, calcite $(\mathrm{Cc})$ and plagioclase $(\mathrm{Pl})$, and the refinement results of illite content for R1 illite-smectite using the Ufer et al. (2012a, b) model and iron content for chlorite IIb. (b) Raman spectra of the $\mathrm{OH}$ stretching region of kaolinite, R1 illite-smectite and chlorite from conduit samples C16-2-6 and C8-2-1
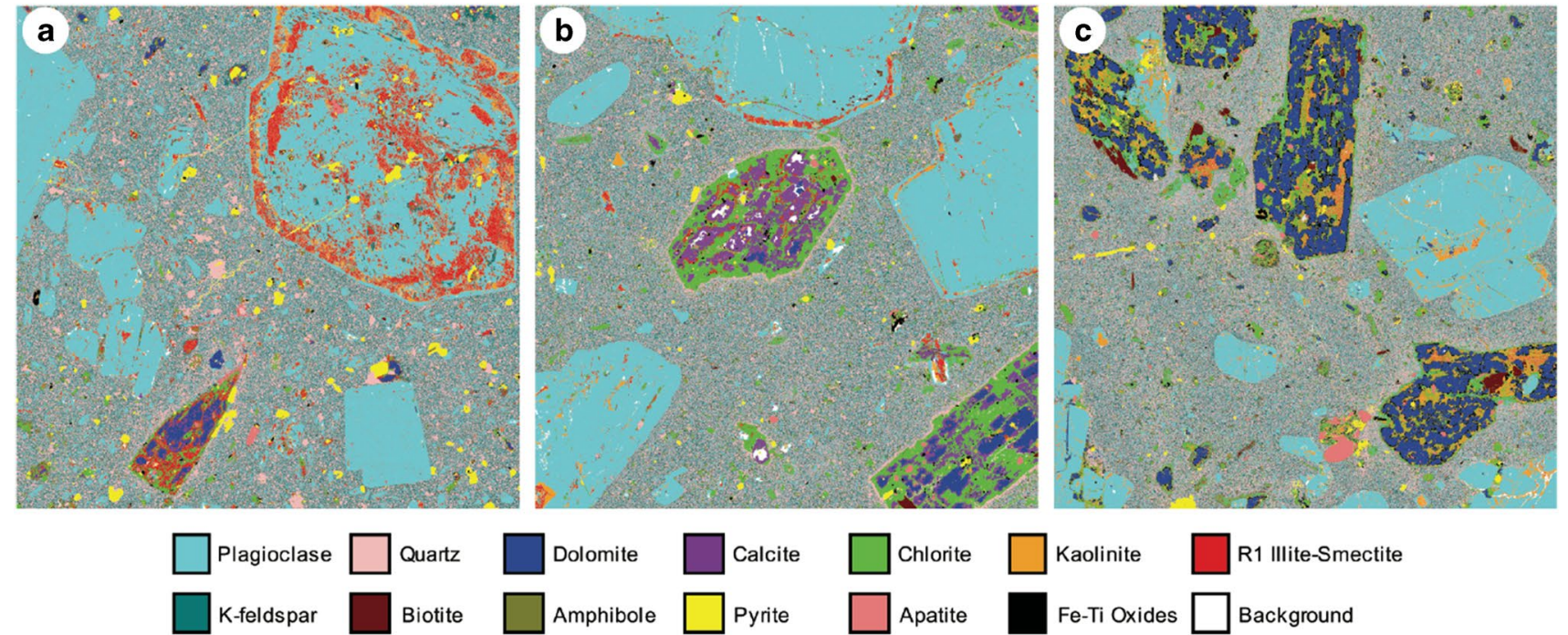

Fig. 3 QEMSCAN images highlighting the mineralogy and the hydrothermal alteration textures. (a) Sample C8-2-1 showing a typical R1 I-S altered rim in a plagioclase crystal (upper right corner). (b) Sample C14-1-5 showing calcite and dolomite alteration of horn- blendes as well as R1 I-S rims in plagioclase crystals. (c) Sample C16-1-2 shows that hornblendes in C16 are affected by intense dolomite alteration. Each image is $1.5 \mathrm{~mm}$ across from left to right 
complex textural and mineralogical overprint due to hydrothermal alteration. The altered rocks contain 13 to $40 \mathrm{vol} . \%$ secondary minerals (Table 1).

The selective alteration of the conduit dykes is restricted to infill of porosity and complete replacement of amphibole and, in part, biotite. Plagioclase phenocrysts show conspicuous oscillatory growth zoning with some 50-300- $\mu$ m-wide zones near the rims of the crystals (Fig. 2) that were leached and are now mostly filled with clay minerals (Fig. 4a). Micro-fractures (5-20- $\mu \mathrm{m}$-wide) that crosscut the groundmass and plagioclase phenocrysts are also filled with alteration phases (Fig. 4b).

We identified two distinct and superimposed clay alteration phases: (i) an early kaolinite and illite-smectite stage (argillic alteration) and (ii) a subsequent chlorite-carbonate stage (propylitic alteration) that can both be further divided into early and late substages.

The earliest and rarest alteration phase is kaolinite with a characteristic deep blue cathodoluminescence (Fig. 5; Götze et al. 2002). It occurs as up to $30-\mu \mathrm{m}$-long and about 5 - $\mu$ m-thick stacks (Fig. 4c) that partly infills porous growth zones and fractures in plagioclase phenocrysts (in all samples) and more rarely occurs as patches in altered amphibole. $\mathrm{XRD}$ analysis indicates that the content of kaolinite is generally low $(<1 \mathrm{wt} . \%)$ with unusually high concentrations of 2-3 wt.\% in sample C16.

Illite-smectite (I-S), which is associated to kaolinite, is more abundant and amounts to about $3-11 \mathrm{wt}$.\% of the bulk sample. Rietveld refinement of oriented glycolated mounts suggests that the interstratified phase is illite-rich (70-75 wt.\%) with a Reichweite 1 (R1) ordering (Fig. 2). The structural formulae based on electron microprobe analyses indicate a dominant tetrahedral (beidellitic) charge and a sodium-rich exchangeable cation composition of the smectite layers (Table 2). The R1 I-S occurs as large, platy crystals, up to $10 \mu \mathrm{m}$ in diameter and often in the form of rosette-like aggregates (Fig. 4). The R1 illite-smectite often occurs together with kaolinite in the porous growth zones within plagioclase phenocrysts as well as in amphibole. Detailed observation of the boundaries between illite-smectite and kaolinite (Fig. 4b, c) suggests that illite-smectite fills the cavities between the kaolinite stacks and is therefore younger. Anhedral pyrite and marcasite are associated with illite-smectite alteration.

The 5-20- $\mu \mathrm{m}$-wide chlorite-sulfide \pm carbonate veinlets crosscutting earlier argillic alteration (Fig. 4b, c) are considered as a distal or low-temperature subtype of propylitic alteration (Corbett and Leach, 1998; Cooke et al. 2014; Wilkinson et al. 2015). The trioctahedral chlorites are $\mathrm{Mg}$ Fe-rich and do not show any signs of interstratification with expandable minerals in XRD analysis (Fig. 2). However, the chemical analyses reveal some minor amounts of $\mathrm{Ca}, \mathrm{Na}$ and especially $\mathrm{K}$, mostly in the plagioclase host (Table 3). The veinlets led to the occurrence of feather textures extending into I-S suggesting replacement of the interstratified minerals by chlorite (Fig. 4d). Carbonates occur late within hornblende pseudomorphs with anatase and in some veinlets with colloform banding and a chemical evolution from Fe-rich dolomite (ankerite) and dolomite to late calcite. Calcite was not detected in sample C16-1-1. The carbonates reveal constant carbon isotope values ranging from -6.2 to $-4.5 \%$ V-PDB and more variable oxygen isotope values of 6.1 to $10.2 \%$ V-SMOW. The two early stage $\mathrm{Fe}$-rich dolomite samples range more on the heavy side of the range (Table 4).
Table 1 Quantitative phase analysis from X-ray powder diffraction analysis (XRD) versus automated scanning electron microscopy using QEMSCAN (QS) analysis of dikes $\mathrm{C} 8, \mathrm{C} 13, \mathrm{C} 14, \mathrm{C} 15$ and C16 (samples C8-1-2, C8-2-1, C8-2-2; C13-2-5, C13-3-4; C14-1-5, C14-4-1; C15-2-6; C15-1-10; C16-1-5, C16-2-6)

\begin{tabular}{lllllllllll}
\hline Sample & C8 & & C13 & & C14 & & C15 & & C16 & \\
Method* & XRD & QS & XRD & QS & XRD & QS & XRD & QS & XRD & QS \\
Number of analyses & 3 & 1 & 2 & 1 & 2 & 1 & 2 & 1 & 2 & 1 \\
vol.\% estimates & & & & & & & & & & \\
Quartz & $29-30$ & 31 & $31-36$ & 34 & $28-32$ & 32 & $31-39$ & 34 & $33-36$ & 33 \\
Plagioclase & $35-40$ & 36 & $33-39$ & 32 & $21-36$ & 35 & $28-35$ & 32 & $33-36$ & 36 \\
K-Feldspar & $8-13$ & 9 & $10-14$ & 11 & $8-9$ & 10 & $9-12$ & 8 & $12-13$ & 10 \\
Hornblende & n.d & n.d & n.d & 1 & n.d & 1 & n.d & 1 & n.d & 1 \\
Biotite & $<1$ & 1 & $2-3$ & 1 & $1-2$ & 2 & $1-2$ & 2 & $0-1$ & 1 \\
Chlorite & $7-8$ & 6 & $2-9$ & 11 & $7-8$ & 10 & $3-5$ & 10 & $3-4$ & 9 \\
Kaolinite & $<0.5$ & 0.6 & $<0.5$ & 0.8 & $<0.5$ & 0.5 & $<0.5$ & 0.8 & $1-2$ & 2.5 \\
Illite-smectite & $5-6$ & 8 & $4-9$ & 4 & $3-6$ & 3 & $8-11$ & 7 & $5-8$ & 3 \\
Pyrite, marcasite & $<1$ & 2 & $<1$ & 1 & $4-5$ & 1 & $3-5$ & 1 & $3-5$ & 1 \\
Calcite & $2-11$ & 1 & $1-2$ & 2 & $1-2$ & 2 & $1-2$ & 3 & n.d & n.d \\
(Fe-)Dolomite & $0-1$ & 2 & $0-1$ & n.d & $0-23$ & 2 & $<1$ & 1 & $2-5$ & 5 \\
Total alteration vol.\% & $17-26$ & 20 & $13-17$ & 17 & $21-40$ & 18 & $19-21$ & 21 & $14-19$ & 17 \\
\hline
\end{tabular}

n.d. refers to 'not detected' 

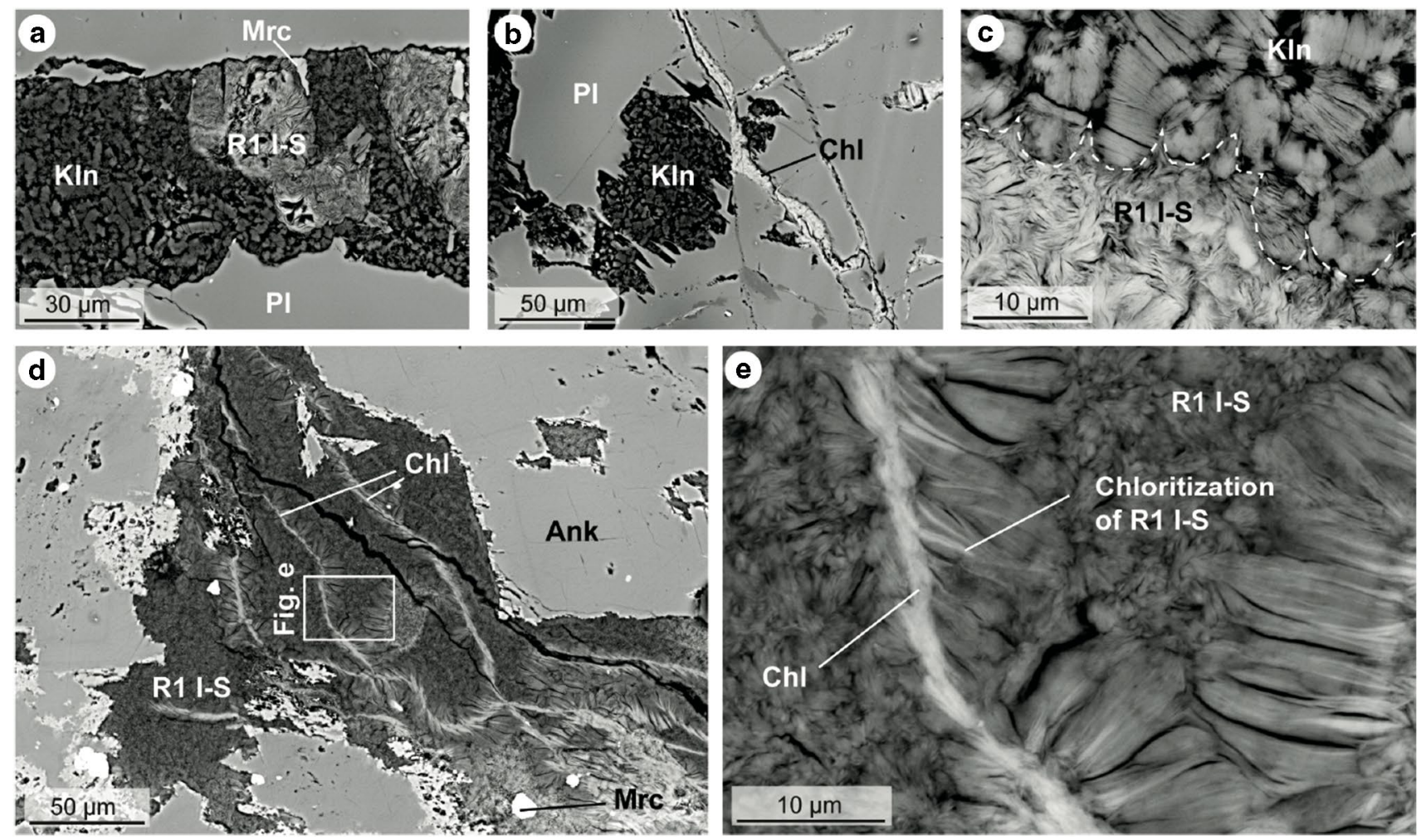

Fig. 4 SEM images of conduit dyke samples. (a) A rim in plagioclase $(\mathrm{Pl})$ filled with kaolinite $(\mathrm{Kln})$, patches of R1 I-S and marcasite (Mrc); sample C13-2-5. (b) Irregular shaped rim (note fine pinshaped structures) filled with Kln. Kln is crosscut by a $20-\mu \mathrm{m}$-wide chlorite veinlet; C13-2-5. (c) Irregular shaped boundary (stippled line) between Kln and R1 I-S indicating a growth of R1 I-S into the

\section{Discussion}

\section{Can we constrain the timescales of alteration?}

In order to assign timescales to the alteration, it is crucial to constrain the timing of emplacement of the dyke material in the subsurface. Noguchi et al. (2008) used groundmass textures and geochemical methods to suggest that the $\mathrm{C} 14$ dyke material is consistent with the 1991-1995 dome materials, drawing a petrogenetic link between the subsurface drill material and a specific eruptive deposit at the surface. Those authors tentatively suggest that the other $\mathrm{C} 8, \mathrm{C} 13$ and C15-C16 materials are therefore related to other eruptive episodes. By contrast, Almberg et al. (2008) analysed C14 and C16 materials in detail and interpreted them to be the feeder dykes for the 1991-1995 dome material. Finally, Goto et al. (2008) compared the chemical and isotopic composition of the dykes with the dome material and associated all of C13, C14, C15 and C16, to the 1991-1995 episode. Our new results show that $\mathrm{C} 16$ has more kaolinite and no carbonate present, which could suggest that it is the more recent and less thoroughly altered dyke in the subsurface. However, pore volume between kaolinite stacks; sample C14-1-5. (d) Hornblende replaced by ankerite (Ank) and R1 I-S. 10-15- $\mu \mathrm{m}$-wide chlorite $(\mathrm{Chl})$ veinlets crosscut the pseudomorph after hornblende in sample C16-1-5. The white rectangle indicates a zoom which is represented in (e). (e) Feathered structures fade into the surrounding R1 I-S indicating a chloritization of the R1 I-S

we note that our results also suggest variability within each dyke sample, and broad consistency between dykes.

Based on the uncertainty as to whether a specific dyke in the Unzen subsurface is the feeder dyke, or if perhaps all of the dykes are part of the feeder complex, we make the simplifying assumption that all of $\mathrm{C} 13-\mathrm{C} 16$ are consistent with the 1991-1995 dome material. Therefore, we can assign the alteration in these dykes a maximum timescale of formation during cooling: the difference between the time of the eruptions 1991-1995 and the drilling 2003-2004 is 7-11 years, with an average of 9 years (Almberg et al. 2008; Goto et al. 2008).

If the conduit zone were to cool by conduction alone over a 9-year period, the temperature at $1600 \mathrm{~m}$ depth would have been expected to be $600-775{ }^{\circ} \mathrm{C}$ at the time of drilling (Nakada et al. 2005; Sakuma et al. 2008). This suggests that fluid circulation may have accelerated cooling by advection of heat through fluid-saturated fractures (e.g. Tretner et al. 2008). Observations of active hydrothermal activity at the surface along the flanks of Unzen and in other parts of the Shimabara Peninsula, the unexpectedly low borehole temperature of $160-180{ }^{\circ} \mathrm{C}$ (Goto 

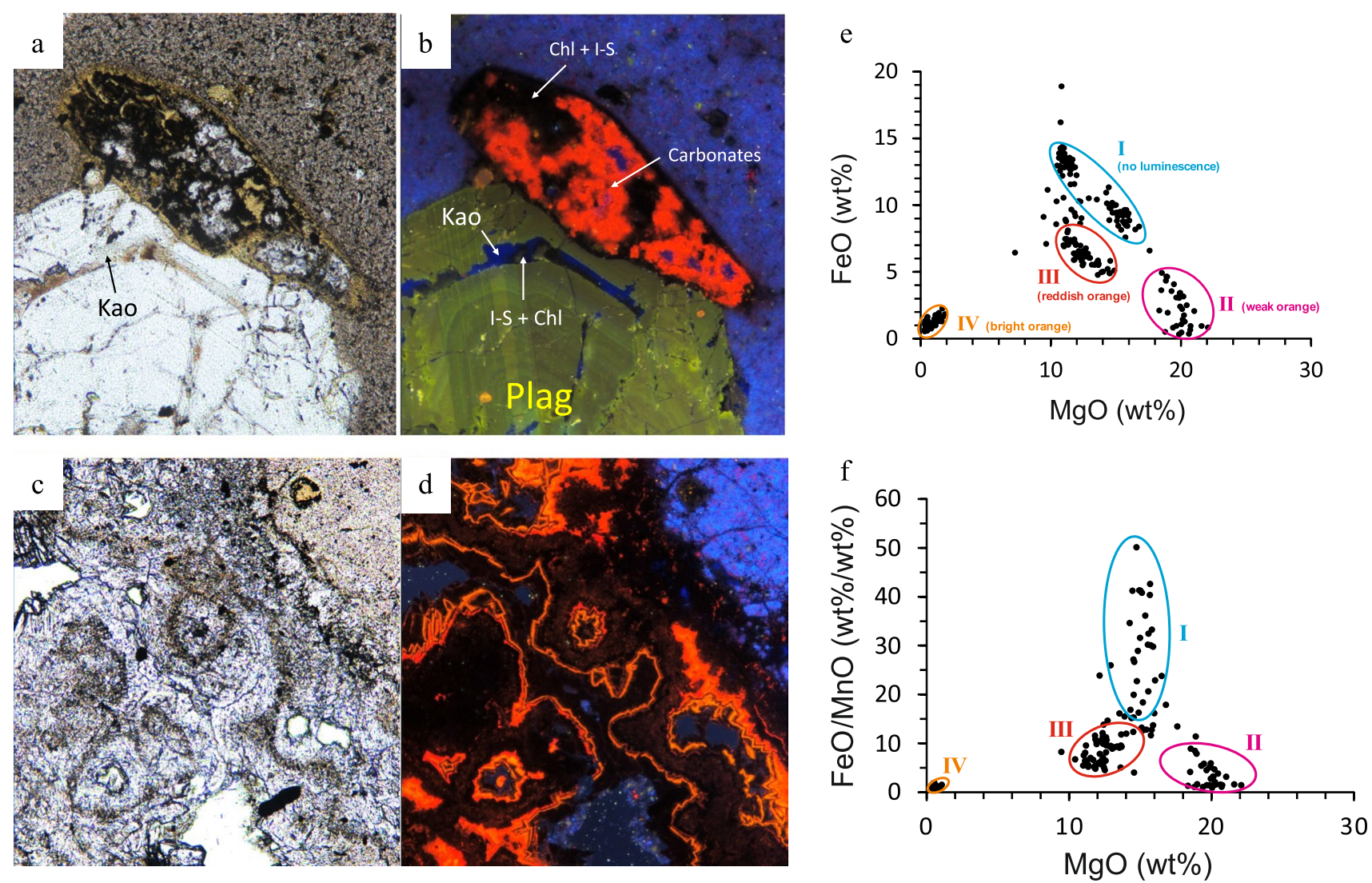

Fig. 5 Photomicrographs of thin sections in plane-polarized light (a, c) and corresponding hot CL image (b, d) showing alteration pattern of plagioclase and amphibole phenocrysts (C15-2-6; a, b) and various generations of carbonate infill with bright red to orange luminescent $\mathrm{Fe}$-poor dolomite and calcite and non-luminescent Fe-rich dolomite (C8-2-1; c, d). Abbreviations: Chl, chlorite; I-S, illite-smectite;

et al. 2008; Suto et al. 2008), and the argillic to propylitic alteration assemblages, are all indicative of the efficient action of heated groundwater circulation, which rapidly cooled and altered the conduit magma. Fluid circulation not only induces cooling that proceeds more quickly than by conduction alone, but is the mechanism by which rapid alteration can take place by precipitation and fluid-rock interaction, which modify the mineralogical and structural make-up of the rock, as well as subsequent fluid circulation and stress evolution (Ramsay 1980; Sibson 1996). This necessarily requires that the dykes and surrounding breccia rocks were permeable to fluids (Sakuma et al. 2008). We note that a peripheral hot spring did not show any significant change between measurements made in 1987 and made in 2005. This appears to suggest that the hydrothermal system was stable over this time frame, which encompasses the 1991-1995 eruption episode (Saibi and Ehara 2010). In turn, this supports our observations that the alteration in the Unzen subsurface is broadly similar from dyke to dyke.
Kao, kaolinite; Plag, plagioclase. (e, f) Chemical composition of various generations (I to IV) of carbonates with their CL colour. The earliest carbonate generation shows high $\mathrm{FeO} / \mathrm{MnO}$ values that quench the CL luminescence. Note that the latest stages IV calcites were not detected in sample C16-1-1

The earliest alteration phases here are kaolinite and R1 I-S, clay minerals that are generally thought to form below $200{ }^{\circ} \mathrm{C}$ (Horton 1985; Inoue 1995; Seedorff et al. 2005; Wilson 2013). Early argillic alteration temperatures in the Unzen feeder dykes, however, are constrained between observed drill core temperatures of 160 to $180{ }^{\circ} \mathrm{C}$ and about $290{ }^{\circ} \mathrm{C}$ based on the absence of pyrophyllite (Hemley et al. 1980). These high-temperature estimates and the absence of dickite, nacrite, R3 I-S, illite or alunite are notable (Seedorff et al. 2005; Wilson 2013) and possibly relate to the rapid cooling, reducing conditions and unusually short alteration history of the samples. We note that chlorite thermometry (e.g. Cathelineau 1988; Jowett 1991; Lanari et al. 2014) yields highly variable temperatures depending on the model used and may be related to small amounts of interstratification with expandable minerals, but results bracket the drilling temperature (as low as $115^{\circ}$ $\mathrm{C}$ and as high as $230^{\circ} \mathrm{C}$; Table 3). At the upper end of this range, the high temperatures for kaolinite would require very low alkali metal cation to proton ratios (Hemley and 
Table 2 Chemical composition of illite-smectite (I-S) in plagioclase (Plag) and hornblende ( $\mathrm{Hbl})$. Illitesmectite structural formulae calculated on an $\mathrm{O}_{10}(\mathrm{OH})_{2}$ anion basis (samples C8-1-2, C13-2-5, C14-1-5, C15-2-6, C16-1-5)

\begin{tabular}{lllllllllll}
\hline & $\mathrm{I}-\mathrm{S}$ & $\mathrm{I}-\mathrm{S}$ & $\mathrm{I}-\mathrm{S}$ & $\mathrm{I}-\mathrm{S}$ & $\mathrm{I}-\mathrm{S}$ & $\mathrm{I}-\mathrm{S}$ & $\mathrm{I}-\mathrm{S}$ & $\mathrm{I}-\mathrm{S}$ & $\mathrm{I}-\mathrm{S}$ & $\mathrm{I}-\mathrm{S}$ \\
$\mathrm{Host}$ min- & $\mathrm{Plag}$ & Plag & Plag & Plag & Plag & $\mathrm{Hbl}$ & $\mathrm{Hbl}$ & $\mathrm{Hbl}$ & $\mathrm{Hbl}$ & $\mathrm{Hbl}$ \\
\hline $\mathrm{SiO}_{2}$ & & & & & & & & & & \\
$\mathrm{TiO}_{2}$ & 0.02 & 0.03 & 0.00 & 0.03 & 0.02 & 0.03 & 0.05 & 0.03 & 0.00 & 0.04 \\
$\mathrm{Al}_{2} \mathrm{O}_{3}$ & 31.02 & 30.36 & 30.25 & 30.64 & 30.61 & 33.57 & 32.87 & 32.40 & 32.62 & 32.34 \\
$\mathrm{Cr}_{2} \mathrm{O}_{3}$ & 0.03 & 0.04 & 0.00 & 0.01 & 0.05 & 0.00 & 0.01 & 0.01 & 0.03 & 0.00 \\
$\mathrm{FeO}$ & 0.59 & 0.54 & 0.71 & 0.70 & 0.71 & 0.87 & 0.78 & 0.59 & 0.53 & 0.57 \\
$\mathrm{MnO}$ & 0.03 & 0.01 & 0.00 & 0.01 & 0.03 & 0.02 & 0.00 & 0.04 & 0.00 & 0.00 \\
$\mathrm{MgO}$ & 1.65 & 1.54 & 1.68 & 1.76 & 1.71 & 0.92 & 1.74 & 1.59 & 1.53 & 1.49 \\
$\mathrm{CaO}$ & 0.24 & 0.23 & 0.23 & 0.30 & 0.28 & 0.26 & 0.23 & 0.19 & 0.27 & 0.21 \\
$\mathrm{Na}_{2} \mathrm{O}$ & 0.71 & 0.63 & 0.60 & 0.86 & 0.75 & 0.79 & 0.77 & 0.56 & 0.83 & 0.74 \\
$\mathrm{~K}_{2} \mathrm{O}$ & 6.11 & 6.15 & 6.02 & 6.19 & 6.03 & 6.85 & 6.32 & 5.34 & 6.27 & 6.29 \\
$\mathrm{Total}$ & 93.89 & 91.11 & 91.43 & 93.77 & 92.72 & 95.22 & 96.32 & 91.95 & 95.50 & 94.78 \\
$\mathrm{Si}$ & 3.47 & 3.45 & 3.46 & 3.47 & 3.45 & 3.34 & 3.39 & 3.38 & 3.41 & 3.41 \\
$\mathrm{Al}^{\mathrm{IV}}$ & 0.53 & 0.55 & 0.54 & 0.53 & 0.55 & 0.66 & 0.61 & 0.62 & 0.59 & 0.59 \\
$\mathrm{Al}^{\mathrm{VI}}$ & 1.84 & 1.84 & 1.84 & 1.81 & 1.83 & 1.89 & 1.85 & 1.90 & 1.86 & 1.86 \\
$\mathrm{Fe}^{2+}$ & 0.03 & 0.03 & 0.04 & 0.04 & 0.04 & 0.05 & 0.04 & 0.03 & 0.03 & 0.03 \\
$\mathrm{Mg}^{2+}$ & 0.16 & 0.15 & 0.17 & 0.17 & 0.17 & 0.09 & 0.16 & 0.16 & 0.15 & 0.14 \\
$\mathrm{Ca}^{2+}$ & 0.02 & 0.02 & 0.02 & 0.02 & 0.02 & 0.02 & 0.02 & 0.01 & 0.02 & 0.01 \\
$\mathrm{Na}^{+}$ & 0.09 & 0.08 & 0.08 & 0.11 & 0.10 & 0.10 & 0.09 & 0.07 & 0.10 & 0.09 \\
$\mathrm{~K}^{+}$ & 0.51 & 0.52 & 0.51 & 0.51 & 0.51 & 0.56 & 0.51 & 0.45 & 0.51 & 0.52 \\
\hline
\end{tabular}

Jones 1964) and thus acidic conditions for early alteration. This, together with the first appearance of sulfides, probably indicates a magmatic component in the clay alteration fluid (Hedenquist et al. 2018). Early acidic fluids must also be responsible for leaching of $\mathrm{Ca}$-rich bands in plagioclase and hornblende and thus for formation of voids for fluid circulation and clay precipitation. During later propylitic alteration with sulfide-carbonate precipitation, the $\mathrm{pH}$ and $\mathrm{Fe}$ and $\mathrm{Mg}$ content of the fluid increased and temperatures decreased. The relatively constant carbon isotope values of carbonates $(-5.4 \pm 0.7 \%$ V-PDB) are consistent with a predominant magmatic carbon source (Ohsawa et al. 2002; Ohba et al. 2008; Shinohara et al. 2008) considering carbon isotope fractionation between $\mathrm{CO}_{2}$ and carbonates at temperatures between about 230 and $160{ }^{\circ} \mathrm{C}$ (Bottinga 1968; Chacko et al. 1991; Horita 2014). Assuming the same temperature range and appropriate oxygen isotope fractionation factors (Sheppard et al. 1969; O'Neil et al. 1969; Horita 2014), an oxygen isotope composition of the aqueous carbonate-precipitating fluid of about -3 to $+2 \%$ o can be calculated (Fig. 6). This range of values is heavier than the local meteoric waters ( -7.5 to $-6 \%$; Mizota and Kusakabe 1994; Shinohara et al. 2008; Saibi and Ehara 2010) or the local deep geothermal waters at Obama (-5.3 to $-4.0 \%$; Saibi and Ehara 2010) suggesting the involvement of a magmatic water component (Fig. 6; Ohba et al.
2008; Shinohara et al. 2008). The late-stage calcite of sample $\mathrm{C} 13-2-5$ has a lower ${ }^{18} \mathrm{O}$ content as compared to the other carbonate samples and thus formed from meteoric-dominated waters (Fig. 6).

In this snapshot, we show what alteration in sample/dyke $\mathrm{C} 14$, and potentially $\mathrm{C} 12$ and $\mathrm{C} 15-\mathrm{C} 16$, occurred beneath Mt Unzen, possibly in the 9 years since emplacement of the most recent dykes in 1991-1995. If the dykes from C8, C12 and C15-C16 and their associated alteration stages were associated with an earlier eruptive phase (e.g. 1792), the alteration may have taken on the order of 200 years to develop. Yet, considering the susceptibility of the clays (present in the recently active volcanic conduit region) to breakdown during incursion to temperatures exceeding their stability fields (Weaver et al. 2020), we anticipate that if the alteration had been accumulated since 1792, the clays would have likely devolatilised by the high temperatures sustained during the emplacement of feeder dykes associated with the 1991-1995 eruptions-evidence for such devolatilization is not present in thin section or via SEM images (Fig. 3). Thus, we favour the likelihood that alteration took c.9 years to be generated. The rapidity of secondary mineral precipitations suggests that fluid circulation pathways in active hydrothermal systems may be ephemeral. As such, convective cells are likely to be created and destroyed over short timescales in hydrothermal systems recurrently intruded by 
Table 3 Chemical composition of chlorite in plagioclase

(Plag) and hornblende ( $\mathrm{Hbl})$, structural formulae and chlorite thermometry results. Chlorite structural formulae based on 14 oxygens assuming full site occupancy

\begin{tabular}{|c|c|c|c|c|c|c|c|c|c|}
\hline $\begin{array}{l}\text { Phase } \\
\text { Host mineral }\end{array}$ & $\begin{array}{l}\text { Chl } \\
\text { Plag }\end{array}$ & $\begin{array}{l}\text { Chl } \\
\text { Plag }\end{array}$ & $\begin{array}{l}\text { Chl } \\
\text { Plag }\end{array}$ & $\begin{array}{l}\text { Chl } \\
\text { Plag }\end{array}$ & $\begin{array}{l}\text { Chl } \\
\text { Plag }\end{array}$ & $\begin{array}{l}\text { Chl } \\
\mathrm{Hbl}\end{array}$ & $\begin{array}{l}\text { Chl } \\
\mathrm{Hbl}\end{array}$ & $\begin{array}{l}\text { Chl } \\
\mathrm{Hbl}\end{array}$ & $\begin{array}{l}\text { Chl } \\
\mathrm{Hbl}\end{array}$ \\
\hline $\mathrm{SiO}_{2}$ & 31.86 & 31.24 & 30.73 & 31.85 & 30.29 & 29.71 & 29.82 & 30.62 & 30.23 \\
\hline $\mathrm{TiO}_{2}$ & 0.02 & 0.05 & 0.02 & 0.00 & 0.02 & 0.01 & 0.07 & 0.05 & 0.05 \\
\hline $\mathrm{Al}_{2} \mathrm{O}_{3}$ & 19.65 & 19.58 & 18.47 & 19.23 & 18.43 & 17.79 & 17.56 & 17.39 & 17.18 \\
\hline $\mathrm{Cr}_{2} \mathrm{O}_{3}$ & 0.01 & 0.02 & 0.00 & 0.00 & 0.00 & 0.01 & 0.00 & 0.03 & 0.00 \\
\hline $\mathrm{FeO}$ & 21.52 & 20.99 & 22.36 & 22.79 & 24.31 & 23.70 & 24.88 & 23.32 & 21.31 \\
\hline $\mathrm{MnO}$ & 0.32 & 0.29 & 0.24 & 0.31 & 0.29 & 0.24 & 0.24 & 0.20 & 0.36 \\
\hline $\mathrm{MgO}$ & 13.21 & 13.27 & 12.10 & 13.59 & 12.48 & 14.16 & 14.31 & 16.21 & 17.22 \\
\hline $\mathrm{CaO}$ & 0.18 & 0.32 & 0.21 & 0.18 & 0.20 & 0.22 & 0.20 & 0.21 & 0.20 \\
\hline $\mathrm{Na}_{2} \mathrm{O}$ & 0.12 & 0.27 & 0.14 & 0.26 & 0.17 & 0.21 & 0.17 & 0.29 & 0.23 \\
\hline $\mathrm{K}_{2} \mathrm{O}$ & 0.74 & 0.67 & 0.72 & 0.55 & 0.35 & 0.05 & 0.02 & 0.04 & 0.09 \\
\hline Total & 87.63 & 86.70 & 84.99 & 88.76 & 86.54 & 86.10 & 87.27 & 88.36 & 86.87 \\
\hline $\mathrm{Si}$ & 3.23 & 3.20 & 3.24 & 3.21 & 3.17 & 3.12 & 3.11 & 3.13 & 3.11 \\
\hline $\mathrm{Al}^{\mathrm{IV}}$ & 0.77 & 0.80 & 0.76 & 0.79 & 0.83 & 0.88 & 0.89 & 0.87 & 0.89 \\
\hline $\mathrm{Al}^{\mathrm{VI}}$ & 1.58 & 1.57 & 1.54 & 1.50 & 1.45 & 1.33 & 1.27 & 1.22 & 1.20 \\
\hline $\mathrm{Ti}$ & 0.00 & 0.00 & 0.00 & 0.00 & 0.00 & 0.00 & 0.01 & 0.00 & 0.00 \\
\hline $\mathrm{Cr}$ & 0.00 & 0.00 & 0.00 & 0.00 & 0.00 & 0.00 & 0.00 & 0.00 & 0.00 \\
\hline $\mathrm{Fe}^{2+}$ & 1.83 & 1.80 & 1.97 & 1.92 & 2.13 & 2.08 & 2.17 & 1.99 & 1.84 \\
\hline $\mathrm{Mn}$ & 0.03 & 0.03 & 0.02 & 0.03 & 0.03 & 0.02 & 0.02 & 0.02 & 0.03 \\
\hline $\mathrm{Mg}$ & 2.00 & 2.03 & 1.90 & 2.04 & 1.95 & 2.22 & 2.23 & 2.47 & 2.64 \\
\hline $\mathrm{Ca}$ & 0.02 & 0.04 & 0.02 & 0.02 & 0.02 & 0.02 & 0.02 & 0.02 & 0.02 \\
\hline $\mathrm{Na}$ & 0.02 & 0.05 & 0.03 & 0.05 & 0.03 & 0.04 & 0.03 & 0.06 & 0.05 \\
\hline K & 0.10 & 0.09 & 0.10 & 0.07 & 0.05 & 0.01 & 0.00 & 0.01 & 0.01 \\
\hline \multicolumn{10}{|l|}{ Chlorite thermometry $\left({ }^{\circ} \mathrm{C}\right)$} \\
\hline Cathelineau (1988) & 185 & 194 & 182 & 192 & 205 & 221 & 224 & 220 & 223 \\
\hline Jowett (1991) & 191 & 200 & 189 & 198 & 212 & 227 & 230 & 224 & 227 \\
\hline Lanari et al. (2014) Chl(2) & 115 & 109 & 118 & 120 & 125 & 137 & 146 & 155 & 158 \\
\hline
\end{tabular}

magma with implications for the long-term energy potential and exploitability of such geothermal systems.

\section{Implications for the subsurface permeability structure}

The pervasive and potentially rapid nature of the alteration raises questions about the influence of alteration on the properties of the subsurface magma and edifice rocks. Hightemperature deformation experiments using Unzen dome samples as a starting material show that the transition from

Table 4 Carbon and oxygen isotope composition of carbonates

\begin{tabular}{llll}
\hline Sample & Mineral & $\begin{array}{l}\delta^{13} \mathrm{C}_{\mathrm{V}-\mathrm{PDB}} \\
{[\% \text { ] }}\end{array}$ & $\begin{array}{l}\delta^{18} \mathrm{O}_{\mathrm{V}-\mathrm{SMOW}} \\
{[\% \text { o }}\end{array}$ \\
\hline $\mathrm{C} 8-1-2$ & Calcite & -5.78 & 9.52 \\
$\mathrm{C} 13-2-5$ & Calcite & -6.17 & 6.05 \\
$\mathrm{C} 14-1-5$ & Ankerite & -4.52 & 9.18 \\
$\mathrm{C} 14-1-5$ & Calcite & -4.59 & 8.46 \\
$\mathrm{C} 15-2-1$ & Calcite & -6.08 & 7.52 \\
$\mathrm{C} 16-1-5$ & Ankerite & -5.19 & 10.18 \\
\hline
\end{tabular}

the conditions for viscous flow to the conditions for viscoelastic fracture development is met during ascent (Cordonnier et al. 2009; Coats et al. 2018). This is consistent with field evidence for rupture of the melt and scaling analysis for this process during eruption (Goto 1999). This implies that the magma itself transitions to a more open-pore system, developing syn-emplacement fracture permeability (Lavallée et al. 2013), consistent with the fractured nature of the USDP-4 dyke samples (Fig. 4). However, the fractures are partially filled with pore-filling alteration minerals (Fig. 4), which may have reduced the permeability again. We can test this hypothesis that the magma underwent an opening and closing cycle from emplacement to cooling and alteration, by using published permeability values at Mt Unzen. Scheu et al. (2008) and Kendrick et al. (2021) determined the permeability of the 1991-1995 dome materials sampled from pyroclastic flow deposits, showing them to be weakly porosity-dependent, representing the unaltered state of the Unzen material. By contrast, for a given porosity, the permeability of the subsurface USDP-4 (or USDP-1) dyke materials is consistently lower (Watanabe et al. 2008; 


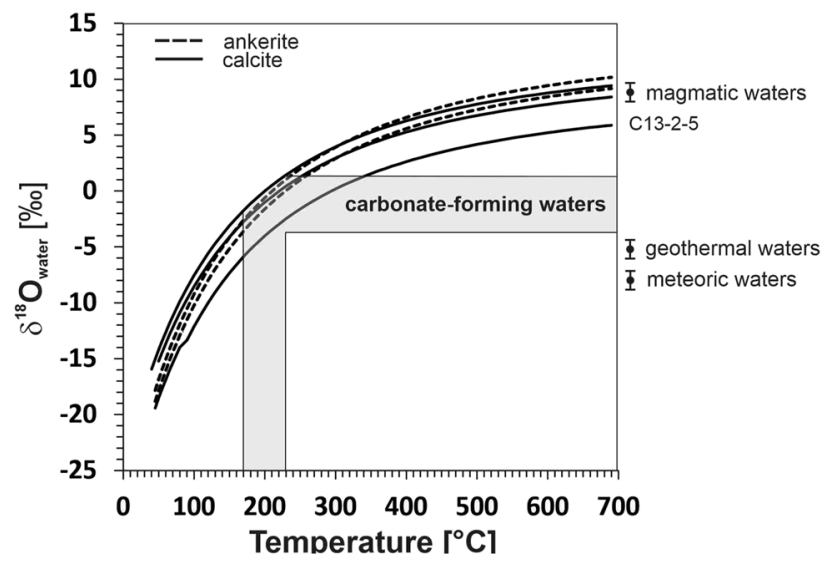

Fig. 6 Calculated oxygen isotope compositions of waters in equilibrium with carbonate samples from Unzen conduit dyke at various temperatures. The grey band indicates isotope composition of waters in equilibrium with the majority of carbonate samples from propylitic veins at the inferred formation temperatures $\left(180-230{ }^{\circ} \mathrm{C}\right)$ in comparison with local meteoric (Mizota and Kusakabe 1994), geothermal (Saibi and Ehara 2010) and magmatic waters at Mt Unzen (Shinohara et al. 2008; Ohba et al. 2008). A magmatic component is suggested for the propylitic alteration fluid. Late-stage calcite from sample C13$2-5$ probably formed from hydrothermal fluids with a larger meteoric water component

Komori et al. 2010). Indeed, the C14 dyke material—which is most likely to be associated with the 1991-1995 eruptions (Noguchi et al. 2008) — has the lowest permeability relative to the dome material (Fig. 7). This data compilation shows that alteration significantly lowers the permeability (by 2-6 orders of magnitude) of the Unzen feeder system by filling the fractures with alteration minerals.

Heap et al. (2019) report a similar result for Merapi volcano, albeit in the dome rocks and without access to the subsurface feeder system. At Merapi volcano, it seems that the general trend of permeability with porosity for unaltered dome contrasts to altered dome rocks (Kushnir et al. 2016; Heap et al. 2019), due to fracture- and pore-filling alteration mineral growth. In Fig. 7, we compare the available Unzen data with Merapi data to show that the general effect of alteration on permeability is strikingly similar for both settings. Therefore, we posit that alteration of cooling dome-forming magma appears to be a self-limiting process because as alteration progresses, pores close, permeability to fluids drops, and so hydrothermal circulation may shut off.

The evidence for porosity and permeability changes associated with alteration has further implications for the strength of the conduit zone and the trajectory that any subsequent dyke emplacement or eruption episode may take. While alteration of the original mineralogical assemblage of volcanic rocks can result in weakening (Wyering et al. 2014; Mordensky et al. 2019a; Heap et al. 2019), the reduction of porosity and permeability via secondary

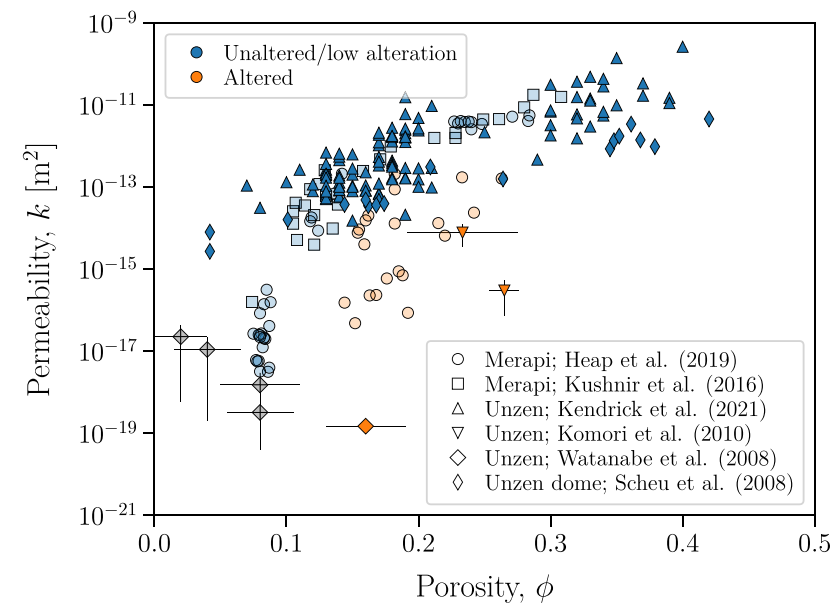

Fig. 7 The permeability of samples from dome-forming volcanic systems: Mt Unzen volcano (Scheu et al. 2008; Watanabe et al. 2008; Komori et al. 2010; Kendrick et al. 2021) and Merapi volcano (Kushnir et al. 2016; Heap et al. 2019). The confining pressures of these measurements were $1 \mathrm{MPa}$ (Kushnir et al. 2016; Heap et al. 2019), 0-50 MPa (Watanabe et al. 2008), 15-500 MPa (Komori et al. 2010), unconfined (Kendrick et al. 2021; note that this reference also contains additional confined data) or is not-stated and presumed to be $<1 \mathrm{MPa}$ (Scheu et al. 2008). For the data from Watanabe et al. (2008), we use error bars to represent the variability in the data as confining pressure was varied. For the data from Komori et al. (2010), we take the extrapolated value of permeability estimated to be the value at depth at the USDP-1 drill site. The "unaltered/low alteration' data from Mt Unzen (Scheu et al. 2008; Kendrick et al. 2021) are from the 1991-1995 dome material preserved in pyroclastic density current deposits at the surface, whereas the 'altered' samples are from the Unzen subsurface in USDP-1 (Komori et al. 2010) or USDP-4 (Watanabe et al. 2008), showing that permeability is $\sim 2-6$ orders of magnitude lower in the altered subsurface (or $~$ $1-3$ orders of magnitude lower, following the correction for samplescale fractures from Heap et al. 2019). The datapoint marked C-14 (Fig. 4c) represents the lowest permeability and the most altered (Table 1) of the Unzen subsurface, and is the USDP-4 drill core sample most petrologically similar to the 1991-1995 dome rocks (Noguchi et al. 2008). The samples marked in grey are from the USDP-4 samples that are petrologically dissimilar to the 1991-1995 dome rocks, and may be related to earlier eruptive episodes. The data from Merapi volcano are all from the surficial dome rocks from that site, but from various eruptive episodes (Kushnir et al. 2016; Heap et al. 2019), showing that the effect of pervasive alteration on permeability appears to be consistent regardless of the depth of alteration. Note that 'porosity' refers to the connected porosity here

mineral precipitation appears to have a larger effect than the alteration itself, and therefore can result in a slight strengthening (Coats et al. 2018; Weaver et al. 2020). The implication is that subsequent ascending dyke-hosted magma may not break through the previous, stronger, altered dyke zone, and may find a route in the weaker surrounding breccia material-consistent with the USDP-4 drill core material in which dykes are spaced interleaved with breccia. However, subsequent dyke emplacement 
would add a significant heat source to the conduit zone, potentially causing thermal breakdown of the alteration minerals in previous dyke materials (Mordensky et al. 2019b; Weaver et al. 2020), with potential to re-weaken them and enhance permeability. Without a more accurate picture of the relative timing of the emplacement of $\mathrm{C} 8$, C13 and C15-C16 dykes, we cannot directly account for the thermal effect of staggered dyke emplacement episodes on the stability of alteration minerals at Unzen.

\section{Conclusions}

The USDP-4 drill core material provides an unprecedented snapshot of alteration processes in the volcanic subsurface. Mt Unzen conduit samples are characterized by selective, moderate but unusually high-temperature argillic alteration of kaolinite and R1 illite-smectite overprinted by propylitic alteration of chlorite, sulfides and carbonates. This alteration was accompanied by an accelerated cooling of the conduit magma. Together, these lines of evidence suggest that the conduit zone beneath Mt Unzen is highly fractured and permeable to hydrothermal fluids down to the phenocryst length scales, and that fluid flow caused the rapid alteration within 9 years and accelerated cooling of the magma.

Acknowledgements Thanks to Richard Worden, Alfons van den Kerkhof, Florian Duschl, Phil Rieger, Donja Aßbichler, Dirk Müller, Michael Joachimski, Cristian Montanaro and Bettina Scheu for analytical or sampling assistance.

Funding Funding was provided by the German Research Foundation (DFG) within the Priority Programme - International Continental Scientific Drilling Program (project HE 4546/6-1) and QEMSCAN funding was provided by FEI. D.B.D. wishes to acknowledge the support of the ERC 2009 ADV Grant 247076 (EVOKES) and ERC 2018 ADV Grant 834225 (EAVESDROP). Y.L. acknowledges the support of an ERC Starting Grant on 'Strain Localisation in Magmas' (SLiM, No. 306488). Jackie E. Kendrick was supported by an Early Career Fellowship of the Leverhulme Trust (ECF-2016-325).

Open Access This article is licensed under a Creative Commons Attribution 4.0 International License, which permits use, sharing, adaptation, distribution and reproduction in any medium or format, as long as you give appropriate credit to the original author(s) and the source, provide a link to the Creative Commons licence, and indicate if changes were made. The images or other third party material in this article are included in the article's Creative Commons licence, unless indicated otherwise in a credit line to the material. If material is not included in the article's Creative Commons licence and your intended use is not permitted by statutory regulation or exceeds the permitted use, you will need to obtain permission directly from the copyright holder. To view a copy of this licence, visit http://creativecommons.org/licenses/by/4.0/.

\section{References}

Almberg LD, Larsen JF, Eichelberger JC et al (2008) Comparison of eruptive and intrusive samples from Unzen Volcano, Japan: effects of contrasting pressure-temperature-time paths. J Volcanol Geotherm Res 175:60-70. https://doi.org/10.1016/j.jvolgeores.2008. 03.020

Ball JL, Calder ES, Hubbard BE, Bernstein ML (2013) An assessment of hydrothermal alteration in the Santiaguito lava dome complex, Guatemala: implications for dome collapse hazards. Bull Volcanol 75:1-18. https://doi.org/10.1007/s00445-012-0676-Z

Ball JL, Stauffer PH, Calder ES, Valentine GA (2015) The hydrothermal alteration of cooling lava domes. Bull Volcanol 77:102. https://doi. org/10.1007/s00445-015-0986-Z

Bergmann J, Friedel P, Kleeberg R (1998) BGMN - a new fundamental parameters based Rietveld program for laboratory X-ray sources, it's use in quantitative analysis and structure investigations. IUCr Comm Powder Diffr Newsl 20:5-8

Bottinga Y (1968) Calculation of fractionation factors for carbon and oxygen isotopic exchange in the system calcite-carbon dioxidewater. J Phys Chem 72:800-808. https://doi.org/10.1021/j1008 $49 \mathrm{a} 008$

Byrdina S, Friedel S, Vandemeulebrouck J et al (2017) Geophysical image of the hydrothermal system of Merapi volcano. J Volcanol Geotherm Res 329:30-40. https://doi.org/10.1016/j.jvolgeores. 2016.11.011

Cashman K V., Sparks RSJ, Blundy JD (2017) Vertically extensive and unstable magmatic systems: a unified view of igneous processes. Science (80- ) 355. https://doi.org/10.1126/science.aag3055

Cathelineau M (1988) Cation site occupancy in chlorites and illites as a function of temperature. Clay Miner 23(4):471-485

Chacko T, Mayeda TK, Clayton RN, Goldsmith JR (1991) Oxygen and carbon isotope fractionations between $\mathrm{CO} 2$ and calcite. Geochim Cosmochim Acta 55:2867-2882. https://doi.org/10.1016/00167037(91)90452-B

Coats R, Kendrick JE, Wallace PA et al (2018) Failure criteria for porous dome rocks and lavas: a study of Mt. Unzen, Japan. Solid Earth 9:1299-1328. https://doi.org/10.5194/se-9-1299-2018

Colombier M, Wadsworth FFB, Gurioli L et al (2017) The evolution of pore connectivity in volcanic rocks. 462 . https://doi.org/10.1016/j. eps1.2017.01.011

Cooke DR, Hollings P, Wilkinson JJ, Tosdal RM (2014) Geochemistry of porphyry deposits. Treatise Geochem, 2nd Edition, 13:357-381. https://doi.org/10.1016/B978-0-08-095975-7.01116-5

Corbett GJ, Leach TM (1998) Southwest Pacific Rim gold-copper systems: structure, alteration, and mineralization (SEG Special Publication No. 6). Society of Economic Geologists, Littleton. $236 \mathrm{p}$

Cordonnier B, Hess K-U, Lavallee Y, Dingwell DB (2009) Rheological properties of dome lavas: case study of Unzen volcano. Earth Planet Sci Lett 279:263-272. https://doi.org/10.1016/j.epsl.2009.01.014

Cordonnier B, Caricchi L, Pistone M et al (2012) The viscous-brittle transition of crystal-bearing silicic melt: direct observation of magma rupture and healing. Geology 40:611-614. https://doi.org/ $10.1130 / \mathrm{G} 3914.1$

Delmelle P, Bernard A, Kusakabe M et al (2000) Geochemistry of the magmatic-hydrothermal system of Kawah Ijen volcano, East Java, Indonesia. J Volcanol Geotherm Res 97(31-53):31-53

Farquharson J, Heap MJ, Baud P et al (2016) Pore pressure embrittlement in a volcanic edifice. Bull Volcanol 78:1-19. https://doi.org/ 10.1007/s00445-015-0997-9

Ghassemi A, Suresh Kumar G (2007) Changes in fracture aperture and fluid pressure due to thermal stress and silica dissolution/precipitation induced by heat extraction from subsurface rocks. Geothermics 36:115-140. https://doi.org/10.1016/j.geothermics.2006.10.001 
Gonnermann HM, Manga M (2003) Explosive volcanism may not be an inevitable consequence of magma fragmentation. Nature 426:432-435

Goto A (1999) A new model for volcanic earthquake at Unzen Volcano: melt rupture model. Geophys Res Lett 26:2541-2544. https://doi. org/10.1029/1999GL900569

Goto Y, Nakada S, Kurokawa M et al (2008) Character and origin of lithofacies in the conduit of Unzen volcano, Japan. J Volcanol Geotherm Res 175:45-59. https://doi.org/10.1016/j.jvolgeores.2008.03. 041

Gottlieb P, Wilkie G, Sutherland D et al (2000) Using quantitative electron microscopy for process mineralogy applications. JOM 52:24 25. https://doi.org/10.1007/s11837-000-0126-9

Götze J, Plötze M, Götte T et al (2002) Cathodoluminescence (CL) and electron paramagnetic resonance (EPR) studies of clay minerals. Mineral Petrol 76:195-212. https://doi.org/10.1007/s007100200041

Heap MJ, Kennedy BM (2016) Exploring the scale-dependent permeability of fractured andesite. Earth Planet Sci Lett 447:139-150. https://doi.org/10.1016/j.epsl.2016.05.004

Heap MJ, Kennedy BM, Farquharson JI et al (2017) A multidisciplinary approach to quantify the permeability of the Whakaari/White Island volcanic hydrothermal system (Taupo Volcanic Zone, New Zealand). J Volcanol Geotherm Res 332:88-108. https://doi.org/10. 1016/j.jvolgeores.2016.12.004

Heap MJ, Troll VR, Kushnir ARL et al (2019) Hydrothermal alteration of andesitic lava domes can lead to explosive volcanic behaviour. Nat Commun 10:1-10. https://doi.org/10.1038/s41467-019-13102-8

Hedenquist JW, Taguchi S, Shinohara H (2018) Features of large magmatic-hydrothermal systems in Japan: characteristics similar to the tops of porphyry copper deposits. Resour Geol 68(2):164-180

Hemley JJ, Jones WR (1964) Chemical aspects of hydrothermal alteration with emphasis on hydrogen metasomatism. Econ Geol 59:538569. https://doi.org/10.2113/gsecongeo.59.4.538

Hemley JJ, Montoya JW, Marinenko JW, Luce RW (1980) Equilibria in the system $\mathrm{Al} 2 \mathrm{O} 3-\mathrm{SiO} 2-\mathrm{H} 2 \mathrm{O}$ and some general implications for alteration/mineralization processes. Econ Geol 75:210-228. https:// doi.org/10.2113/gsecongeo.75.2.210

Horita J (2014) Oxygen and carbon isotope fractionation in the system dolomite-water-CO2 to elevated temperatures. Geochim Cosmochim Acta 129:111-124. https://doi.org/10.1016/j.gca.2013.12.027

Hornby AJ, Lavallée Y, Kendrick JE et al (2019) Brittle-ductile deformation and tensile rupture of dome lava during inflation at Santiaguito, Guatemala. J Geophys Res Solid Earth 124:10107-10131. https:// doi.org/10.1029/2018JB017253

Horton DG (1985) Mixed-layer illite/smectite as a paleotemperature indicator in the Amethyst vein system, Creede district, Colorado, USA. Contrib Mineral Petrol 91:171-179. https://doi.org/10.1007/ BF00377764

Horwell CJ, Williamson BJ, Llewellin EW et al (2013) The nature and formation of cristobalite at the Soufrière Hills volcano, Montserrat: implications for the petrology and stability of silicic lava domes. Bull Volcanol 75:1-19

Ikeda R, Kajiwara T, Omura K, Hickman S (2008) Physical rock properties in and around a conduit zone by well-logging in the Unzen Scientific Drilling Project, Japan. J Volcanol Geotherm Res 175:13-19. https://doi.org/10.1016/j.jvolgeores.2008.03.036

Inoue A (1995) Formation of clay minerals in hydrothermal environments. In: Origin and Mineralogy of Clays. Springer Berlin Heidelberg, pp 268-329

Jowett EC (1991) Fitting iron and magnesium into the hydrothermal chlorite geothermometer. In: GAC/MAC/SEG Joint Annual Meeting, Toronto, Program with Abstracts, pp 16

Kagiyama T, Utada H, Yamamoto T (1999) Magma ascent beneath Unzen Volcano, SW Japan, deduced from the electrical resistivity structure. J Volcanol Geotherm Res 89:35-42. https://doi.org/10. 1016/S0377-0273(98)00120-6
Kendrick JE, Schaefer LN, Schauroth J, Bell AF, Lamb OD, Lamur A, Miwa T, Coats R, Lavallée Y, Kennedy BM (2021) Physical and mechanical rock properties of a heterogeneous volcano: the case of Mount Unzen, Japan. Solid Earth 12:633-664. https://doi.org/10. 5194/se-12-633-2021

Komori S, Kagiyama T, Hoshizumi H et al (2010) Vertical mapping of hydrothermal fluids and alteration from bulk conductivity: simple interpretation on the USDP-1 site, Unzen Volcano, SW Japan. J Volcanol Geotherm Res 198:339-347. https://doi.org/10.1016/j. jvolgeores.2010.09.019

Kumagai H, Chouet BA, Nakano M (2002) Temporal evolution of a hydrothermal system in Kusatsu-Shirane Volcano, Japan, inferred from the complex frequencies of long-period events. J Geophys Res Solid Earth 107:ESE 9-1-ESE 9-10. https://doi.org/10.1029/ $2001 \mathrm{jb} 000653$

Kushnir ARL, Martel C, Bourdier JL et al (2016) Probing permeability and microstructure: unravelling the role of a low-permeability dome on the explosivity of Merapi (Indonesia). J Volcanol Geotherm Res 316:56-71. https://doi.org/10.1016/j.jvolgeores.2016.02.012

Kyne R, Hollings P, Jansen NH, Cooke DR (2013) Supergene and hypogene halloysite in a porphyry-epithermal environment at Cerro La Mina, Chiapas, Mexico. Econ Geol 108:1147-1161. https://doi.org/ 10.2113/econgeo.108.5.1147

Lamb OD, De Angelis S, Umakoshi K et al (2015) Repetitive fracturing during spine extrusion at Unzen volcano, Japan. Solid Earth 6:1277-1293. https://doi.org/10.5194/se-6-1277-2015

Lamur A, Kendrick JE, Eggertsson GH et al (2017) The permeability of fractured rocks in pressurised volcanic and geothermal systems. Sci Rep 7:6173. https://doi.org/10.1038/s41598-017-05460-4

Lanari P, Wagner T, Vidal O (2014) A thermodynamic model for ditrioctahedral chlorite from experimental and natural data in the system $\mathrm{MgO}-\mathrm{FeO}-\mathrm{Al}_{2} \mathrm{O}_{3}-\mathrm{SiO}_{2}-\mathrm{H}_{2} \mathrm{O}$ : Applications to P-T sections and geothermometry. Contrib Miner Petrol 167(2):968

Lavallée Y, Hess K-U, Cordonnier B, Dingwell DB (2007) Non-Newtonian rheological law for highly crystalline dome lavas. Geology 35:843-846. https://doi.org/10.1130/g23594a.1

Lavallée Y, Benson PM, Heap MJ et al (2013) Reconstructing magma failure and the degassing network of domebuilding eruptions. Geology 41:515-518. https://doi.org/10.1130/G33948.1

López DL, Williams SN (1993) Catastrophic volcanic collapse: relation to hydrothermal processes. Science (80- ) 260:1794-1796. https:// doi.org/10.1126/science.260.5115.1794

Mizota C, Kusakabe M (1994) Spatial distribution of.DELTA.D-. DELTA.18O values of surface and shallow groundwaters from Japan, south Korea and east China. Geochem J 28:387-410. https:// doi.org/10.2343/geochemj.28.387

Moore D, Reynolds (1989) X-ray diffraction and the identification and analysis of clay minerals. 2nd Ed. Oxford University Press, Oxford.

Mordensky SP, Heap MJ, Kennedy BM et al (2019a) Influence of alteration on the mechanical behaviour and failure mode of andesite: implications for shallow seismicity and volcano monitoring. Bull Volcanol 81.https://doi.org/10.1007/s00445-019-1306-9

Mordensky SP, Kennedy BM, Villeneuve MC et al (2019) Increasing the permeability of hydrothermally altered andesite by transitory heating. Geochem Geophys Geosyst 20:5251-5269. https://doi.org/ 10.1029/2019GC008409

Nakada S, Uto K, Sakuma S et al (2005) Scientific results of conduit drilling in the Unzen Scientific Drilling Project (USDP). Sci Drill 1:18-22. https://doi.org/10.5194/sd-1-18-2005

Neuser RD, Bruhn F, Götze J et al (1995) Kathodolumineszenez: Methodik und Anwendung. Zentralblatt für Geol und Paläontologie 1:287-306

Noguchi S, Toramaru A, Nakada S (2008) Groundmass crystallization in dacite dykes taken in Unzen Scientific Drilling Project (USDP-4). J Volcanol Geotherm Res 175:71-81. https://doi.org/10.1016/j.jvolg eores.2008.03.037 
O'Neil JR, Clayton RN, Mayeda TK (1969) Oxygen isotope fractionation in divalent metal carbonates. J Chem Phys 51:5547-5558. https:// doi.org/10.1063/1.1671982

Ohba T, Hirabayashi J, Nogami K et al (2008) Magma degassing process during the eruption of Mt. Unzen, Japan in 1991 to 1995: modeling with the chemical composition of volcanic gas. J Volcanol Geotherm Res 175:120-132. https://doi.org/10.1016/j.jvolgeores. 2008.03.040

Ohsawa S, Kazahaya K, Yasuhara M et al (2002) Escape of volcanic gas into shallow groundwater systems at Unzen Volcano (Japan): evidence from chemical and stable carbon isotope compositions of dissolved inorganic carbon. Limnology 3:169-173. https://doi.org/ 10.1007/s102010200020

Pouchou JL, Pichoir F (1985) PAP ( $\varphi \rho \mathrm{z}$ ) procedure for improved quantitative microanalysis. In: Armstrong JT (ed) Microbeam analysis. San Francisco Press, San Francisco, pp 104-106

Ramsay JG (1980) The crack-seal mechanism of rock deformation. Nature 284:135-139. https://doi.org/10.1038/284135a0

Rosas-Carbajal M, Komorowski JC, Nicollin F, Gibert D (2016) Volcano electrical tomography unveils edifice collapse hazard linked to hydrothermal system structure and dynamics. Sci Rep 6.https:// doi.org/10.1038/srep29899

Rosenbaum J, Sheppard SMF (1986) An isotopic study of siderites, dolomites and ankerites at high temperatures. Geochim Cosmochim Acta 50:1147-1150. https://doi.org/10.1016/0016-7037(86) 90396-0

Rowland JV, Simmons SF (2012) Hydrologic, magmatic, and tectonic controls on hydrothermal flow, Taupo Volcanic Zone, New Zealand: implications for the formation of epithermal vein deposits. Econ Geol 107:427-457. https://doi.org/10.2113/econgeo.107.3.427

Saibi H, Ehara S (2010) Temperature and chemical changes in the fluids of the Obama geothermal field (SW Japan) in response to field utilization. Geothermics 39:228-241. https://doi.org/10.1016/j.geoth ermics.2010.06.005

Sakuma S, Kajiwara T, Nakada S et al (2008) Drilling and logging results of USDP-4 - penetration into the volcanic conduit of Unzen Volcano, Japan. J Volcanol Geotherm Res 175:1-12. https://doi.org/ 10.1016/j.jvolgeores.2008.03.039

Scheu B, Kueppers U, Mueller S et al (2008) Experimental volcanology on eruptive products of Unzen volcano. J Volcanol Geotherm Res 175:110-119. https://doi.org/10.1016/j.jvolgeores.2008.03.023

Seedorff E, Dilles JH, Proffett JMJ et al (2005) Porphyry deposits: characteristics and origin of hypogene features. Economic Geology, 100th anniversary volume, society of economic geologsts, Littleton, pp 251-298

Sheppard SMF, Nielsen RL, Taylor HP (1969) Oxygen and hydrogen isotope ratios of clay minerals from porphyry copper deposits. Econ Geol 64:755-777. https://doi.org/10.2113/gsecongeo.64.7.755

Shiina T, Nakajima J, Matsuzawa T (2013) Seismic evidence for high pore pressures in the oceanic crust: implications for fluid-related embrittlement. Geophys Res Lett 40:2006-2010. https://doi.org/ $10.1002 / \mathrm{grl} .50468$

Shinohara H, Ohba T, Kazahaya K, Takahashi H (2008) Origin of volcanic gases discharging from a cooling lava dome of Unzen volcano, Japan. J Volcanol Geotherm Res 175:133-140. https://doi. org/10.1016/j.jvolgeores.2008.03.024

Sibson RH (1996) Structural permeability of fluid-driven fault-fracture meshes. J Struct Geol 18:1031-1042. https://doi.org/10.1016/01918141(96)00032-6

Sparks RSJ, Annen C, Blundy JD, Cashman KV, Rust AC, Jackson MD (2019) Formation and dynamics of magma reservoirs. Phil Trans R Soc A 377:20180019
Srigutomo W, Kagiyama T, Kanda W et al (2008) Resistivity structure of Unzen Volcano derived from time domain electromagnetic (TDEM) survey. J Volcanol Geotherm Res 175:231-240. https://doi.org/10. 1016/j.jvolgeores.2008.03.033

Sugimoto T, Ishibashi H, Wakamatsu S, Yanagi T (2005) Petrologic evolution of Pre-Unzen and Unzen magma chambers beneath the Shimabara Peninsula, Kyushu, Japan: evidence from petrography and bulk rock chemistry. Geochem J 39:241-256. https://doi.org/ 10.2343/geochemj.39.241

Suto Y, Sakuma S, Takahashi H et al (2008) Temperature memory gauge survey and estimation of formation temperature of the USDP-4 conduit hole at Unzen Volcano, Japan. J Volcanol Geotherm Res 175:20-27. https://doi.org/10.1016/j.jvolgeores.2008.03.034

Tretner A, Zimmer M, Erzinger J et al (2008) Real-time drill mud gas logging at the USDP-4 drilling, Unzen volcano, Japan. J Volcanol Geotherm Res 175:28-34. https://doi.org/10.1016/j.jvolgeores. 2008.03.031

Ufer K, Kleeberg R, Bergmann J, Dohrmann R (2012a) Rietveld refinement of disordered illite-smectite mixed-layer structures by a recursive algorithm. II: powder-pattern refinement and quantitative phase analysis. Clays Clay Miner 60:535-552. https://doi.org/10.1346/ CCMN.2012.0600508

Ufer K, Kleeberg R, Bergmann J, Dohrmann R (2012b) Rietveld refinement of disordered illite-smectite mixed-layer structures by a recursive algorithm. I: one-dimensional patterns. Clays Clay Miner 60:507-534. https://doi.org/10.1346/CCMN.2012.0600507

Umakoshi K, Shimizu H, Matsuwo N (2001) Volcano-tectonic seismicity at Unzen volcano, Japan, 1985-1999. J Volcanol Geotherm Res 112:117-131. https://doi.org/10.1016/S0377-0273(01)00238-4

Vasseur J, Wadsworth FB (2019) The permeability of columnar jointed lava. J Geophys Res Solid Earth 124:11305-11315. https://doi.org/ 10.1029/2019JB018118

Wadsworth FB, Witcher T, Vossen CEJ et al (2018) Combined effusive-explosive silicic volcanism straddles the multiphase viscousto-brittle transition. Nat Commun 9:1-8. https://doi.org/10.1038/ s41467-018-07187-w

Wallace PA, Kendrick JE, Miwa T et al (2019) Petrological architecture of a magmatic shear zone: a multidisciplinary investigation of strain localisation during magma ascent at Unzen Volcano, Japan. J Petrol 60:791-826. https://doi.org/10.1093/petrology/egz016

Watanabe T, Shimizu Y, Noguchi S, Nakada S (2008) Permeability measurements on rock samples from Unzen Scientific Drilling Project Drill Hole 4 (USDP-4). J Volcanol Geotherm Res 175:82-90. https://doi.org/10.1016/j.jvolgeores.2008.03.021

Wilkinson JJ, Chang Z, Cooke DR, Baker MJ, Wilkinson CC, Inglis S, Gemmell JB (2015) The chlorite proximitor: a new tool for detecting porphyry ore deposits. J Geochem Explor 152:10-26. https:// doi.org/10.1016/j.gexplo.2015.01.005

Weaver J, Eggertsson GH, Utley JEP et al (2020) Thermal liability of hyaloclastite in the Krafla geothermal reservoir, Iceland : the impact of phyllosilicates on permeability and rock strength Research Article Thermal Liability of Hyaloclastite in the Krafla Geothermal Reservoir, Iceland : the impact. hindawi.com.https://doi.org/10. $1155 / 2020 / 9057193$

Wilson M (2013) Rock-forming minerals, volume 3C, sheet silicates: Clay minerals. 2nd Ed. The Geological Society, London

Wyering L, Villeneuve M, Of IW-P of the GS, 2014 U (2014) The effect of hydrothermal alteration on drillability-a study looking at mechanical specific energy, Bingham Index and Alteration Strength Index. Proc Geol Soc Am 46 